\title{
DIALOG ANTROPOLOGIS ANTARAGAMA DENGAN SPIRITUALITAS PASSING OVER
}

\author{
Stephanus Turibius Rahmat \\ Program Studi Pendidikan Guru PAUD STKIP Santu Paulus \\ Jl. Jend. Ahmad Yani, No. 10, Ruteng - Flores, Indonesia \\ E-mail: stephan_rahmat@yahoo.com
}

\begin{abstract}
Inter-religious dialogue is very important discourse in the context of many religions in Indonesia. Inter-religious dialogue is the efforts to solve the difficulty of a relationship among each other followers of religions in which some conflicts and strained situations often happened. This article is a theoretical study in the purpose to describe the matter of inter-religious dialogue and formulate the model of inter-religious dialogue for creating the tolerance, the harmony, the safeness, and the peace in the religious life. By using the librarian research, the resulting study discovered that any models of inter-religious dialogue can be categorized into two models of inter-religious dialogue that are 'theological-spiritual dialogue' and 'social humanity dialogue'. Theologically and spiritually, all religions have a universal message and passing over spirit (out of the border of religions) in greatly committing to the human values. Anthropologically, the presence of all religion aims to bring the enlightenment and the enthusiasm of life among their adherents. It can be concluded that anthropological dialogue based on passing over spirituality is one of the interaction model in inter-religious dialogue, or positive and constructive communication which is oriented to create the safeness and the peace in the religious life, based on passing over spirituality, in which all religions have the initial spirit of the presence that religion plays a role to illuminate (illuminative), save (prophetic), liberate (liberative) and transform (transformative). Here, religion has a self-image as rahmatan lil 'alamin.
\end{abstract}

Keywords:

Dialogue; anthropological; interreligious; spirituality, passing over.

\begin{abstract}
Abstrak
Dialog antaragama merupakan bahasan yang sangat penting dalam konteks kemajemukan agama di Indonesia. Dialog antaragama pada dasarnya merupakan serangkaian usaha untuk memecah kebekuan hubungan antarumat beragama yang sering melahirkan konflik dan ketegangan. Artikel ini merupakan kajian teoritis yang bertujuan untuk mendeskripsikan masalah dialog antaragama dan merumuskan bentuk dialog antaragama dalam rangka menciptakan toleransi, harmoni, rasa aman, dan perdamaian dalam kehidupan beragama. Dengan penelusuran kepustakaan, hasil studi menemukan bahwa bentuk-bentuk dialog antaraagama dapat dirumuskan ke dalam dua bentuk dialog antaragama, yaitu dialog teologis-spiritual dan dialog sosial kemanusiaan. Secara teologis-spiritual, semua agama memiliki pesan universal dan semangat passing over (melintas batas agama-agama) dalam menjunjung tinggi nilai-nilai kemanusiaan. Secara antropologis, kehadiran setiap agama bertujuan untuk membawa pencerahan dan kegairahan hidup bagi masyarakat penganutnya. Dapat disimpulkan bahwa dialog antropologis dengan spiritualitas passing over merupakan salah satu bentuk interaksi dalam dialog anataragama, atau komunikasi positif dan konstruktif yang berorientasi pada terciptanya rasa aman dan perdamaian dalam kehidupan beragama, berdasarkan spiritualitas passing over, dimana semua agama memiliki semangat awal kehadiran yakni agama berperan untuk menerangi (iluminatif), kenabian (profetis), membebaskan (liberatif), dan mengubah (transformatif). Semua penganut agama harus hadir secara terus-menerus untuk menumbuhkan semangat toleransi, memperjuangkan perdamaian tanpa kekerasan, dan menyelesaikan masalah kemanusiaan.Disinilah, agama memiliki citra diri sebagai rahmatan lil 'alamin.
\end{abstract}

Kata Kunci:

Dialog; antropologis, antaragama; spiritualitas; passing over.

DOI: $10.15575 / \mathrm{jw} . v 2 \mathrm{i} 2.1704$

Received: October 2017; Accepted: December 2017; Published: December 2017 


\section{A. PENDAHULUAN}

Dialog antaragama merupakan salah satu strategi untuk menjembatani kemajemukan kehidupan beragama serta menciptakan kerukunan hidup beragama di Indonesia. Dialog membuat setiap penganut agama harus memahami agamanya dan menyadari pula keragaman dan perbedaan dalam beragama. Menurut A. Mukti Ali, dalam menyikapi konteks pluralitas kehidupan beragama dewasa ini, setiap agama yang terlibat dalam dialog perlu memiliki prinsip "agree in disagreement" (setuju dalam perbedaan). ${ }^{1}$

Konsep ini jika dijalankan dengan baik akan menciptakan kerukunan dan keharmonisan hidup beragama. Prinsip ini membuat dialog antaragama akan berjalan lancar dan baik. Dialog antaragama merupakan suatu proses komunikasi yang mengutamakan sikap toleransi, membudayakan keterbukaan, saling pengertian, mengembangkan rasa saling menghormati antara penganut agama. Kesadaran seperti ini bersumber dari suatu keyakinan fundamental bahwa kehadiran setiap agama adalah menjalankan fungsi kritis profetisnya dan misi pembebasan bagi semua penganutnya.

Dalam konteks inilah, menurut M. Khusnul Amal bahwa agama diyakini sebagai way of life yang mampu memberikan arahan, tuntunan, dan pendidikan bagi masyarakat dalam berpandangan, bersikap serta berperilaku. ${ }^{2}$ Ajaran agama yang mengandung nilai-nilai seperti keadilan, amanah, persamaan, kedamaian, kasih sayang, tanggung jawab, kemandirian, moralitas serta kerukunan menjadi kekuatan yang sangat potensial untuk terciptanya keharmonisan serta kerukunan hidup beragama.

Dialog antaragama pada dasarnya merupakan serangkaian usaha untuk memberikan

1 Dikutip Abdul Halim, "Pluralisme Dan Dialog Antar Agama," Tajdid 14, no. 1 (2015), 35, http://ejournal.iainjambi.ac.id/index.php/tajdid/article/view/734

${ }^{2}$ Dikutip Mawardi Juned, "Reaktualisasi Kerukunan Antar Umat Beragama Dalam Kemajemukan Sosial," Substantia 17, no. 1 (April 1, 2015), 63, http://substantiajurnal.org/index.php/subs/article/view/1 $29 / 0$. solusi mengenai masalah hubungan antarumat beragama yang sering melahirkan konflik dan ketegangan.

Kajian ini merupakan kajian teoritis dengan menggunakan metode deskriptif dan penelusuran kepustakaan. kajian ini bertujuan untuk mendeskripsikan masalah dialog antaragama, serta berusaha merumuskan bentuk dialog antropologis antaragama dengan spiritualitas passing over dalam rangka menciptakan toleransi, harmoni, rasa aman, dan perdamaian dalam kehidupan beragama. Di sisi lain, kajian ini berusaha memberikan kontribusi pemikiran mengenai bentuk dialog antar agama, serta memberikan tawaran dan mendorong setiap agama supaya menjadikan dialog antropologis antaragama dalam semangat passing over sebagai salah satu strategi menciptakan kerukunan dan kedamaian hidup bersama.

Sistematika pembahasan dalam artikel ini dibagi dalam dua bagian. Pertama, akan mendeskripsikan masalah dialog antar agama, yang secara berurutan akan dibahas mengenai pengertian dialog antaragama, tantangan atau hambatan dalam membangun dialog antaragama, prinsip-prinsip dialog antaragama dan bentuk-bentuk dialog antaragama. Pada bagian terakhir akan dikaji tentang dialog antropologis dengan spiritualitas passing over sebagai model dialog antaragama yang arif, positif, konstruktif dan transformatif.

\section{B. HASIL DAN PEMBAHASAN 1. Dialog Antaragama}

\section{a. Pengertian Dialog Antaragama}

Pengertian dialog sangat luas dan bervariasi. Pembicaraan antara seseorang dengan orang yang lain dapat juga disebut dialog. Percakapan seseorang dengan orang lain melalui perantaraan media, misalnya telepon dapat juga disebut dialog. Dialog ditandai dengan adanya interaksi atau komunikasi yang bersifat monologal, dialogal dan multi-arah. Menurut Save M. Dagun ${ }^{3}$, dialog selalu dihu-

\footnotetext{
${ }^{3}$ Save Dagun, M, Kamus Besar Ilmu Pengetahuan. (Jakarta: Lembaga Pengkajian Kebudayaan Nusantara, 2006), 812.
} 
bungkan dengan suatu pendekatan, maka dikenal istilah pendekatan dialog (dialogic approach). Dialog selalu dikaitkan dengan relasi antara "aku/saya dan yang lain". Relasi ini membentuk beziehung atau dunia tempat orang-orang saling dialog dan saling menyapa.

Selain itu, gambaran tentang dialog secara singkat dapat ditemukan dalam dokumen yang dikeluarkan oleh Dewan Kepausan Untuk Dialog Antaragama. Dokumen ini menyebutkan bahwa dialog dapat dimengerti dalam tiga tingkat ${ }^{4}$, yaitu: Pertama, pada tingkat manusiawi semata-mata. Pada level ini, dialog berarti komunikasi timbal-balik yang terarah kepada satu tujuan bersama, atau pada tingkat yang lebih dalam, terarah kepada persatuan antar pribadi. Kedua, dialog dapat dianggap sebagai suatu sikap hormat dan persahabatan, yang meresapi atau hendaknya meresapi semua kegiatan yang membentuk perutusan setiap agama. Ketiga, dalam konteks keragaman agama, dialog berarti semua hubungan antaragama yang positif dan konstruktif dengan pribadi-pribadi dan komunitas dari agamaagama lain.

Menurut Adolf Heuken, dialog akan terjadi jika pihak-pihak yang terlibat dalam dialog mempunyai kesediaan untuk mendengarkan dan mempertimbangkan uraian dan alasan pihak lain serta berusaha menempatkan diri dalam posisi sebagai partner dialog untuk mencari kepentingan bersama bukan kepentingan kelompok. ${ }^{5}$ Dialog seperti ini berbentuk dialog karya yang mencakup kerja sama dalam proyek kemanusiaan, dialog tematis yang membicarakan tema-tema yang disepakati semua pihak, dialog informal atau kehidupan yang mengandaikan adanya kerukunan, dan dialog formal yang mendalami pokok-pokok tertentu kehidupan beragama. Di sinilah, dialog sebagai pertukaran pikiran

Kongregasi Evangelisasi Bangsa-Bangsa dan Dewan Kepausan Untuk Dialog Antaragama, Dialog dan Pewartaan-Refleksi dan Orientasi Mengenai Dialog Antaragama dan Pewartaan Injil Yesus Kristus (Maumere: LPBAJ, 1991), 8.

${ }^{5}$ Adolf Heuken, Ensiklopedi Gereja I, A-G (Jakarta: Yayasan Cipta Loka Caraka, 1991), 240-241. dengan maksud supaya pendapat/keyakinan masing-masing pihak semakin jelas, sehingga dapat dipahami (bukan hanya diketahui) dengan lebih tepat, keyakinan lain dihormati, meskipun tidak selalu dapat diterima.

Berdasarkan pengertian dialog ini, maka dapat ditegaskan bahwa dialog terjadi antar manusia entah sebagai individu atau satu kelompok yang dibangun di atas landasan berpijak untuk saling hormat-menghormati. Dialog seperti ini bersifat manusiawi dan terarah kepada pencapaian kesepakatan-kesepakatan bersama yang menjadi norma untuk menuntun kehidupan bersama.

Dialog yang sesungguhnya dapat dibangun dengan sikap saling menghargai dan menghormati, keterbukaan dan kemauan baik (political will) dari semua pihak, mulai dari kelompok akar rumput sampai dengan para pengambil keputusan dan kebijakan yang ada dalam semua kelompok. Singkatnya, semua komponen yang terlibat dalam dialog harus menyadari pentingnya dialog sebagai pintu masuk terciptanya kedamaian dan kerukunan hidup bersama.

Berdasarkan pengertian dialog seperti ini, maka dapat dirumuskan bahwa dialog antaragama merupakan komunikasi yang melahirkan hubungan antaragama yang arif, positif, konstruktif, dan transformatif serta diarahkan untuk saling memahami dan saling memperkaya, dalam ketaatan kepada kebenaran, dan hormat terhadap kebebasan. Atas dasar itulah, Ismail R. Faruqi menegaskan bahwa dialog antaragama yang sesungguhnya bukan hanya sekedar pertukaran informasi, seremonial, dan basa-basi, tetapi harus mempunyai sebuah norma keagamaan yang dapat mendamaikan berbagai perbedaan di antara agama-agama. ${ }^{6}$

Dialog antaragama yang positif dan konstruktif harus didasarkan pada prinsip yang jelas serta alasan yang paling fundamental. Menurut Khotimah, dialog antaragama terjadi karena ada dua alasan pokok yakni alasan

\footnotetext{
${ }^{6}$ Dikutip Khotimah, "Dialog dan Kerukunan Antar Umat Beragama," Jurnal Ushuluddin 17, no. 2 (2011), 218, doi:10.24014/JUSH.V17I2.693.
} 
sosiologis dan teologis. ${ }^{7}$ Dasar sosiologis perlunya dialog antaragama adalah dialog dapat membantu setiap peserta untuk tumbuh dalam kepercayaannya sendiri; saling memperkaya diantara agama-agama; membantu untuk meningkatkan kerja sama antaragama. Sedangkan alasan teologis pentingnya dialog antaragama adalah bahwa seluruh umat manusia hanya mempunyai satu asal, yaitu Tuhan, dan diciptakan untuk tujuan akhir yang sama, yaitu Tuhan sendiri; umat manusia adalah satu. Kesatuan tersebut yang mendorong manusia untuk meningkatkan perdamaian universal. Dasar teologis seperti inilah yang mengharuskan agama-agama untuk bersikap positif terhadap agama-agama yang lain.

Menurut A.Mukti Ali, dialog antar agama adalah pertemuan hati dan pikiran antar pemeluk berbagai agama ${ }^{8}$. Dengan demikian, dialog merupakan suatu bentuk komunikasi antara orang-orang yang percaya pada tingkat agama. Dialog menjadi jalan bersama untuk mencapai kebenaran dan kerja sama dalam proyek-proyek yang menyangkut kepentingan bersama. Oleh karena itu, dialog menuntut supaya setiap pihak yang terlibat dialog mempunyai kebebasan beragama supaya setiap orang bebas untuk menguraikan pandangannya kepada orang lain. Hal ini akan memperjelas persamaan dan perbedaan ajaran satu agama dengan ajaran agama lain. Selain itu, dialog juga membiarkan utuh hak setiap orang untuk mengamalkan keyakinan-keyakinannya dan menyampaikannya kepada orang lain.

Selanjutnya, dialog antaragama pada dasarnya merupakan serangkaian usaha tersendiri untuk memecah kebekuan hubungan antarumat beragama yang sering melahirkan konflik dan ketegangan. ${ }^{9}$ Upaya untuk memecah

\footnotetext{
7 Khotimah, "Dialog dan Kerukunan Antar Umat Beragama," 221-222.

8 A.Mukti Ali, "Ilmu Perbandingan Agama, Dialog, Dakwah dan Misi," in Ilmu Perbandingan Agama di Indonesia dan Belanda, ed. oleh Burhanuddin Daja dan Herman Leonard Beck (Jakarta: INIS, 1992), 232.

9 Afif Rifa'i, "Dialektika Pemikiran dalam Dialog Antar Umat Beragama: Studi Kasus Forum Persaudaraan Umat Beriman (FPUB) DI. Yogyakarta," Jurnal Pemberdayaan Masyarakat: Media Pemikiran
}

kebekuan teologis dalam hubungan antara umat beragama dapat ditempuh dengan pencarian titik temu antara agama-agama. Setiap agama mengadakan perjumpaan dan dialog yang konstruktif dan berkesinambungan. Dan setiap pemeluk agama mempunyai kesediaan untuk mendengar dan mengungkapkan diri secara seimbang. Dialog antaragama tidak akan berjalan dengan baik jika masih ada kecurigaan dan prasangka negatif diantara umat beragama. Dialog antaragama akan terjadi jika jika setiap pemeluk agama mempunyai hati yang tulus dan jujur.

Berdasarkan uraian di atas, maka dapat disimpulkan bahwa dialog antaragama berfungsi sebagai sarana untuk berbagi pengalaman supaya terjadi proses saling memperkaya dan mendalami pengalaman serta tradisi keagamaan masing-masing. Dialog antaragama yang dibangun atas dasar kesadaran seperti ini akan menciptakan kedamaian dan kerukunan hidup bersama serta menegaskan suatu keyakinan bersama bahwa pluralitas kehidupan beragama itu sebagai suatu kekayaan yang harus dirawat dalam semangat persaudaraan, persatuan dan kesatuan.

\section{b. Tantangan Dialog Antaragama}

Dialog antaragama mempunyai tantangan dan hambatan yang sangat kompleks. Ada beberapa tantangan, hambatan atau kesulitan pokok yang sering ditemukan dalam dialog, yakni: ${ }^{10}$ (1) Penganut agama kurang memiliki dasar iman yang cukup, kurang mempunyai pengetahuan dan pemahaman yang cukup komprehensif mengenai kepercayaan dan praktik-praktik agama yang lain. Kenyataan seperti ini akan menyebabkan kurangnya penghargaan terhadap makna bahkan kadangkadang menimbulkan gambaran yang salah tentang agama yang lain; (2) Perbedaan bu-

dan Dakwah Pembangunan 1, no. 1 (2017): 75-95, 91, http://ejournal.uin-

suka.ac.id/dakwah/JPMI/article/view/1131.

10 Kongregasi Evangelisasi Bangsa-Bangsa dan Dewan Kepausan Untuk Dialog Antaragama, Dialog dan Pewartaan-Refleksi dan Orientasi Mengenai Dialog Antaragama dan Pewartaan Injil Yesus Kristus, 28-29. 
daya merupakan tantangan tersendiri untuk menjalin dialog. Karena orang sering mengklaim bahwa budayanya paling baik dibandingkan dengan budaya orang lain. Selain itu, perbedaan budaya, tingkat pendidikan, penggunaan bahasa yang berbeda turut menghambat terwujudnya dialog; (3) kurang yakin atas nilai-nilai dialog antar agama itu sendiri. Ada sebagian orang yang beranggapan bahwa dialog itu sebagai tugas khusus para ahli agama. Atau sebagian lagi beranggapan bahwa dialog sebagai salah satu tanda kelemahan atau bahkan pengkhianatan iman yang berujung pada kecurigaan atau prasangka negatif terhadap motif orang dalam dialog. Pandangan seperti inilah yang turut melahirkan sikap intoleran dalam kehidupan beragama; (4) Suasana kehidupan beragama pada zaman ini ditandai dengan bertumbuhnya materialisme, sikap acuh tak acuh dalam hidup beragama, dan menjamurnya sekte-sekte keagamaan yang menciptakan kebingungan dan menimbulkan persoalan-persoalan baru dalam kehidupan beragama. Kesulitan lain yang menghambat dialog antaragama adalah orang merasa diri sudah sangat sempurna sehingga kurang memiliki keterbukaan terhadap yang lain. ${ }^{11}$ Jika seseorang sudah merasa bahwa dirinya telah memiliki kebenaran yang sempurna, maka dirinya tidak akan merasa perlu untuk belajar dari orang lain yang berbeda pandangan. Sikap ini kadang ditunjukkan dengan cara defensif dan agresif.

Hal fundamental yang mendasari munculnya tantangan, hambatan atau kesulitan seperti yang dijelaskan di atas adalah kurangnya pemahaman mengenai hakekat dan tujuan dialog antaragama yang sebenarnya. Oleh karena itu, perlu ada upaya sadar dan berlangsung terus-menerus untuk menerangkan tentang pentingnya dialog antaragama sebagai salah satu media untuk menciptakan kehidupan beragama yang harmonis dan damai. Setiap agama perlu menyadari bahwa keter-

11 Taslim HM. Yasin, "Membangun Hubungan Antaragama Mewujudkan Dialog dan Kerja sama," Substantia 13, no. 1 (April 2011), 90, http://substantiajurnal.org/index.php/subs/article/view/59. libatan dalam dialog tidak tergantung dari kesuksesan mencapai pemahaman timbalbalik serta saling memperkaya. Akan tetapi, setiap agama memang harus terlibat dalam dialog yang berlangsung secara terus-menerus untuk memperjuangkan nilai-nilai kemanusiaan yang bersifat universal. ${ }^{12}$ Oleh karena itu, setiap pemeluk agama yang terlibat dalam dialog perlu membangun sikap saling memercayai, menghargai dan menghormati. Dialog antaragama harus selalu menciptakan atmosfer saling memahami, saling menerima, dan saling berkolaborasi di antara umat beragama yang berbeda (creative praxis).

\section{c. Prinsip-Prinsip Dialog Antaragama}

Dialog antaragama yang bersifat arif, positif, konstruktif dan transformatif mempunyai prinsip atau norma dasar yang menjadi pedoman atau ketentuan yang harus dipenuhi. Dengan itu, dialog antaragama yang terjadi bukan hanya sekedar pertukaran informasi seremonial, dan basi-basi, tetapi mempunyai sebuah norma keagamaan yang dapat mendamaikan berbagai perbedaan di antara agamaagama. Leonard Swidler mengembangkan sepuluh (10) prinsip atau norma dasar dialog antaragama, yakni: ${ }^{13}$ (1) Tujuan awal proses dialog adalah untuk berubah, dan tumbuh dalam persepsi yang benar tentang kenyataan dan selanjutnya bertindak secara tepat; (2) dialog harus merupakan proyek dua sisi yaitu pertama, dialog dalam komunitasnya sendiri (intrareligius) dan selanjutnya dialog dengan komunitas lain (interreligius); (3) setiap partisipan yang memasuki proses dialog ini harus memercayai ketulusan dan kejujuran rekan dialognya; (4) dalam dialog tidak boleh mela-

12 Kongregasi Evangelisasi Bangsa-Bangsa dan Dewan Kepausan Untuk Dialog Antaragama, Dialog dan Pewartaan-Refleksi dan Orientasi Mengenai Dialog Antaragama dan Pewartaan Injil Yesus Kristus, 29.

${ }^{13}$ Efa Ida Amaliyah, "Makna Pluralitas Agama di Kalangan Mahasiswa STAIN Kudus dan Implementasinya Melalui Mata Kuliah Perbandingan Agama," Wawasan: Jurnal Ilmiah Agama dan Sosial Budaya 2, no. 1 (Juni 2017), 7, doi:10.15575/jw.v2i1.587. 
kukan perbandingan atas ideal-ideal agama dengan praktik atau kenyataan agama dari partner dialog; (5) setiap partisipan dialog harus mendefinisikan dirinya sendiri-sebab dalam kenyataannya suatu agama hanya bisa didefinisikan oleh agama itu sendiri- sebaliknya setiap definisi diri yang ditafsirkan oleh partner dialog kita harus diterima dengan lapang dada, sebagai upaya untuk mengenal diri lebih baik; (6) masing-masing partisipan dialog harus menahan diri untuk mencari pokok-pokok perbedaan yang ada ${ }^{14} ;(7)$ dialog hanya bisa terjadi antara pihak-pihak yang selevel atau sama ( par cum pari); (8) proses dialog itu hanya bisa berlangsung melalui basis saling percaya; (9) setiap pribadi yang terlibat dalam dialog harus bisa mengambil sikap kritis, minimal atas dirinya sendiri (gagasan-gagasannya) dan tradisi religius yang diyakininya; (10) setiap partisipan harus berusaha memahami dan mengalami agama atau tradisi agama partner dialognya "dari dalam" (from within).

Selain itu, Raimundo Panikkar menyebutkan bahwa prinsip-prinsip dialog antaragama yang harus dikembangkan adalah harus menghapus setiap bentuk sikap apologi jika ingin bersungguh-sungguh bertemu dengan penganut dari tradisi keagamaan yang lain. ${ }^{15}$ Prinsip seperti ini akan menjadikan dialog antaragama sebagai kesempatan perjumpaan bernuansa persaudaraan untuk saling menyumbang dan menyuburkan kehidupan beragama. Pluralitas

\footnotetext{
${ }^{14}$ Apalagi pokok-pokok perbedaan yang tidak akan mendapatkan titik temu, dimana masing-masing meyakininya sebagai kebenaran dalam doktrin agamanya. Pokok perbedaan ini disebut dengan "non-negotiable things", seperti halnya perbedaan narasi cerita Yesus dalam Alkitab (Bible) dan Alquran, atau perbedaan pokok lainnya. Andai pun didiskusikan, bukan untuk diperdebatkan dan saling klaim kebenaran, namun untuk mencari pemahaman yang lebih baik agar saling memahami dan menghargai perbedaan tradisi agama lain dalam kerangka dialog. Lihat, Husnul Qodim, "The Differences Story of Isa (Jesus) in the Qur'an and the Bible: Study of Comparative Text," RELIGIOUS: Jurnal Agama dan Lintas Budaya 1, no. 1 (2012): 5155.

${ }^{15}$ Khotimah, "Dialog dan Kerukunan Antar Umat Beragama.”, 218.
}

hidup beragama mesti dihayati dalam semangat dialog seperti ini. Prinsip-prinsip ini menjadi dasar dalam menciptakan dan mengembangkan dialog antaragama yang bersifat arif, positif, konstruktif dan transformatif. Dialog antaragama yang didesain seperti ini akan membuat kehidupan bersama yang toleran, dan damai tanpa konflik sosial.

Menurut Paul Budi Kleden, dialog antaragama seperti ini bermakna sebagai keberanian agama-agama untuk mewartakan dan mengamalkan nilai-nilai kemanusiaan yang sudah dikenal sebagai berlaku universal. ${ }^{16}$ Itu berarti bahwa dialog antaragama yang bersifat doktriner tidak akan pernah menemukan kata sepakat, tetapi dialog yang menempatkan religiusitas sebagai tema sentral selalu akan terarah kepada kerja sama yang harmonis antara agama-agama. Dengan kata lain, revitalisasi religiositas merupakan upaya menanggalkan sekam-sekam doktriner dan yang tersisa hanyalah pengalaman universal akan Yang Transenden dan simpati yang tidak kunjung habis atas kemanusiaan. Disinilah, setiap pemeluk agama sebagai insan religius hadir untuk mengupayakan "agama yang berwajah humanis". Agama sebagai institusi yang berpihak dan membela nilai-nilai kemanusiaan yang universal.

\section{d. Bentuk-Bentuk Dialog Antaragama}

Dialog atau perjumpaan dapat menciptakan suasana kehidupan bersama yang rukun dan damai. Oleh karena itu, perlu mengupayakan atau mencari metode dialog yang arif, positif, konstruktif serta transformatif. F.X.E. Armada Riyanto menyebutkan empat bentuk dialog, yakni sebagai berikut: ${ }^{17}$ Pertama, Dialog Kehidupan (bagi semua orang). Setiap pribadi terdorong untuk berdialog karena adanya sikap solidaritas dan rasa kebersamaan yang melekat begitu kuat. Setiap pribadi yang

\footnotetext{
16 Paul Budi Kleden, Dialog Antaragama dalam Terang Filsafat Proses Alfred North Whitehead (Maumere: Ledalero, 2001), 188.

17 F.X.E. Armada Riyanto, Dialog Agama dalam Pandangan Gereja Katolik (Yogyakarta: Kanisius, 1995), 111-113.
} 
terlibat dalam dialog kehidupan ini berusaha hidup dalam kebersamaan dalam suatu semangat keterbukaan dan bertetangga, saling membagi kegembiraan dan dukacita, persoalan-persoalan yang manusiawi dan keprihatinan-keprihatinan iman yang dirasakan setiap hari. Kedua, dialog karya (untuk bekerja sama). Dialog ini mengharuskan seorang pemeluk agama dan pemeluk agama lain untuk bekerja sama demi perkembangan dan pembebasan manusia seutuhnya. Ketiga, dialog tukar-menukar pandangan teologis (untuk Para Ahli). Dialog ini terjadi pada level para ahli. Para ahli berusaha memperdalam pemahaman mengenai warisan religius agamanya masingmasing, dan saling menghargai nilai-nilai rohani setiap agama. Keempat, dialog mengenai pengalaman keagamaan (dialog pengalaman iman). Setiap pribadi yang berakar dalam tradisi agamanya sendiri dapat saling berbagi dalam hal kekayaan rohani agamanya.

A. Mukti Ali juga membuat klasifikasi bentuk-bentuk dialog antaragama yakni (1) dialog kehidupan; (2) dialog kegiatan sosial; (3) dialog komunikasi pengalaman agama; (4) dialog untuk doa bersama; dan (5) dialog untuk berdiskusi masalah-masalah teologis. ${ }^{18}$ Keempat bentuk dialog ini membuat peserta dialog menyatu dalam semangat kekitaan dan kebersamaan tanpa adanya kekhawatiran dan kecurigaan satu sama lain.

Para Neo Modernis merumuskan bentukbentuk dialog tersebut, ke dalam dua bentuk dialog yang dapat dikembangkan dalam kehidupan beragama. Kedua bentuk dialog tersebut diyakini dapat menciptakan makna tentang pluralisme agama dan menghindari konflik atas nama agama. Kedua bentuk dialog tersebut adalah sebagai berikut ${ }^{19}$ : (1) Dialog Teologis-Spiritual. Dialog ini akan bermakna jika setiap pemeluk agama mempunyai keberanian untuk mempertanyakan, menggugat dan mengoreksi diri sendiri sesudah memahami

\footnotetext{
${ }^{18}$ Ali, "Ilmu Perbandingan Agama, Dialog, Dakwah dan Misi.", 233.

${ }^{19}$ Amaliyah, "Makna Pluralitas Agama di Kalangan Mahasiswa STAIN Kudus dan Implementasinya Melalui Mata Kuliah Perbandingan Agama.”, 6.
}

jantung pengalaman keagamaan orang lain. Jika hal ini dilakukan oleh setiap pemeluk agama, maka akan lahir pandangan keagamaan yang bersifat inklusif, terbuka, dan tidak mudah menyalahkan keyakinan keagamaan orang lain. Dialog seperti ini sering disebut dengan dialog intrareligius (intrareligious dialogue); (2) Dialog Sosial Kemanusiaan. Dialog model ini mengharuskan setiap pemeluk agama untuk membicarakan masalah agama dan hubungannya dengan problem kemanusiaan yang terjadi. Setelah itu, setiap pemeluk agama berusaha secara bersama-sama mencari solusi alternatif masalah tersebut. Dalam dialog ini, setiap agama harus berperan kritis untuk menanggapi masalah-masalah sosial kontemporer yang dialami manusia. Dialog seperti ini justru menciptakan persamaan persepsi dan visi masing-masing agama.

Berdasarkan pandangan para New Modernis yang mengkategorikan bentuk-bentuk dialog antaragama dalam dua bentuk, yaitu 'dialog teologis-spiritual' dan 'dialog sosial kemanusiaan' yang diuraikan diatas, penulis menegaskan bahwa kedua bentuk dialog tersebut dapat digabungkan dan diimplementasikan secara bersamaan oleh setiap agama. Secara teologis-spiritual, semua agama memiliki pesan universal dan semangat passing over (melintas batas agama-agama) dalam menjunjung tinggi nilai-nilai kemanusiaan. Secara antropologis, kehadiran setiap agama bertujuan untuk membawa pencerahan dan kegairahan hidup bagi masyarakat penganutnya.

Dengan terlibat langsung dalam kedua bentuk dialog tersebut, setiap penganut agama memiliki tugas yang satu dan sama yakni menyeringkan kekayaan rohani agamanya untuk suatu nilai kemanusiaan yang paling tinggi yakni berjuang atas nama kemanusiaan. Dalam konteks inilah, penulis merumuskannya dalam satu istilah yakni dialog antropologis antaragama dengan spiritualitas passing over.

Setiap agama terlibat dalam dialog yang menjungjung tinggi dan menghormati nilainilai luhur, harkat dan martabat manusia. Setiap agama harus tampil di garda terdepan dalam semangat dialog untuk memper- 
juangkan nilai-nilai kemanusiaan yang bersifat universal. Serentak dengan itu, setiap agama berusaha untuk mencari solusi alternatif atas persoalan-persoalan sosial kemanusiaan yang terjadi dalam kehidupan bersama.

Hal inilah yang ditegaskan oleh Hans Kung, ${ }^{20}$ seorang teolog Kristen terkemuka, bahwa setiap agama memang memiliki dogmanya sendiri yang membuatnya berbeda dengan yang lain, tetapi etika dan perilaku agama-agama memiliki banyak kesamaan. Atas dasar itulah, kita perlu memberi ruang bagi agama lain untuk 'ada' (ko-eksistensi), dan berpartisipasi dalam persoalan-persoalan kemanusiaan.

\section{Dialog Antropologis Antaragama dengan Spiritualitas Passing Over}

Dialog antropologis antaragama dengan semangat passing over sejatinya mau menegaskan bahwa semua agama dipanggil untuk menjadi penjunjung paling utama kemanusiaan. Menurut Franz Magnis-Suseno, semua agama mempunyai semangat dan optimisme yang sama yakni secara kontinu menyerukan dan memperjuangkan agama yang menjunjung tinggi nilai kemanusiaan. ${ }^{21}$ Jika demikian, maka kita masih mempunyai harapan bahwa kebaikan, keterbukaan, toleransi dan sikap saling menghormati akan menang jika dikembangkan secara kontinu dialog antropologis antaragama. Inilah saatnya semua agama berlomba-lomba mewartakan kabar bahagia untuk manusia dan kemanusiaan kepada dunia.

Dialog antropologis antaragama dengan spiritualitas passing over merupakan salah satu bentuk interaksi dalam dialog antaragama, atau komunikasi positif dan konstruktif yang

${ }^{20}$ Komaruddin Hidayat dan Ahmad Gaus AF, ed., Passing Over: Melintas Batas Agama (Jakarta: Gramedia Pustaka Utama, 1998), xi.

${ }^{21}$ Suseno Franz Magnis, "Agama, Kebangsaan dan Demokrasi: Nurcholish Madjid dan Kemanusiaan," dalam Agama, Keterbukaan dan Demokrasi: Tantangan dan Harapan, ed. oleh Ayu Mellisa dan Husni Mubarok (Jakarta: Pusat Studi Agama dan Demokrasi Yayasan Paramadina bekerja sama dengan The Asia Foundation dan The Ford Foundation, 2015), 4. berorientasi pada terciptanya kehidupan manusia bersama yang aman dan damai. Dengan adanya dialog yang berlangsung dalam semangat passing over, dimana semua penganut agama tetap concern pada semangat awal kehadiran agama-agama ${ }^{22}$, yakni agama berperan untuk menerangi (iluminatif), kenabian (profetis), membebaskan (liberatif), dan mengubah (transformatif).

Dialog antropologis dengan spiritualitas passing over sebagai tawaran model dialog antaragama yang arif, positif, konstruktif dan transformatif.

\section{a. Dialog Antropologis Antaragama}

Pluralitas kehidupan beragama hanya bisa dijembatani dengan memperkuat semangat dialog. Dialog bertujuan agar setiap pemeluk agama tetap merawat dan menjaga pluralitas kehidupan beragama. Sebab sering kali terjadi konflik dan ketegangan sosial justru karena ada umat beragama yang mengklaim dirinya paling benar, yang lainnya sesat. Menurut Anis Malik Thoha, klaim seperti ini justru melahirkan keyakinan yang biasa disebut dengan "doctrine of salvation" (doktrin keselamatan). ${ }^{23}$ Dalam doktrin ini ditegaskan bahwa keselamatan (surga) adalah hak para pengikut agama tertentu saja, sedangkan yang lainnya celaka dan akan masuk neraka. Pluralitas kehidupan beragama mesti dihayati dalam suatu formula semangat yang dikemukakan oleh Ahmad Syafi'i Ma'arif yakni "berbeda dalam persaudaraan dan bersaudara dalam perbedaan". ${ }^{24}$ Artinya, jika semua agama berjalan di luar jalur formula ini, maka agama tidak lagi berfungsi sebagai sumber kedamaian dan keamanan, tetapi menjadi sumber sengketa dan kekacauan, bahkan sum-

\footnotetext{
${ }^{22}$ Al Andang, Agama yang Berpijak dan Berpihak (Yogyakarta: Kanisius, 1998), 8.

Anis Malik Thoha, Tren Pluralisme Agama, Tinjauan Kritis (Jakarta: Perspektif, 2005), 1.

24 Tore Lindholm, W.Cole Durham, dan Bahia Tahzib-Lie, ed., Kebebasan Beragama atau Berkeyakinan Seberapa jauh?: Sebuah Referensi tentang Prinsip-Prinsip dan Praktek, diterjemahkan oleh Rafael Edy Bosko dan M. Rifai'i Abduh (Kanisius, 2010), xii.
} 
ber peperangan. Oleh karena itu, cara beragama yang benar harus tampak secara konkret dalam perilaku penganutnya yang jujur, ikhlas, dan lapang dada. Segala bentuk perbedaan yang terlihat dalam sistem teologis masingmasing agama jangan digunakan untuk merenggangkan kualitas persaudaraan lintas umat, tetapi dijadikan sumber untuk saling memperkaya pengalaman keagamaan bangsa ini. Disinilah, penerimaan pluralitas kehidupan beragama tidak dapat dipisahkan dari penerimaan kebebasan beragama. $^{25}$ Masalah yang sering terjadi adalah setiap pemeluk agama selalu berpikir bahwa agama saya yang paling benar, sedangkan agama yang lain selalu salah. Cara berpikir seperti ini mengindikasikan bahwa agama yang satu kurang menerima dan menghargai agama yang lain dan sekaligus kurang menghayati kebenaran yang otentik dalam agamanya. Realitas seperti ini sebenarnya mau membuka mata sekaligus mengajak semua agama supaya menjadi lebih manusiawi dan menumbuhkan motivasi hidup beragama yang benar.

Setiap penganut agama perlu menghadapi perbedaan agama secara bijaksana supaya bisa hidup bersama dalam suasana damai dan produktif. Inilah dasar bagi setiap agama untuk membangun sikap dialog. Dialog hanya bisa terjadi jika setiap pemeluk agama tidak bersikap eksklusif, tidak tunduk pada tradisi, warisan dan latar belakangnya. Keyakinan iman setiap agama harus didasarkan pada suatu landasan rasional yang berasal dari suatu kedalaman diri bahwa setiap agama memiliki kekhasan dan bersikap inklusif. Setiap agama harus bersikap inklusif (terbuka) dan bukan eksklusif (tertutup). Dialog antaragama sebenarnya mau membuka ruang dan kesempatan yang terbuka bagi setiap agama untuk menyadari nilai-nilai kebenaran dan kebaikan yang ditawarkan dan diajarkan setiap agama. Dengan itu, setiap penganut agama harus yakin bahwa agama yang dipeluknya adalah

\footnotetext{
${ }^{25}$ Haryatmoko, Dominasi Penuh Muslihat - Akar Kekerasan dan Diskriminasi (Jakarta: Gramedia, 2010), 102.
}

yang paling benar di seluruh alam raya, namun dalam keseharian ia tidak menunjukkan sikap "sok benar" atau "mau menang sendiri". Atas dasar itulah, A. Malik Thoha mengemukakan bahwa semua agama secara relatif adalah sama, dan tidak ada satu pun agama yang berhak mengklaim diri "uniqueness of truth and salvation" (sebagai satu-satunya kebenaran atau satu-satunya jalan menuju keselamatan). ${ }^{26}$

Setiap agama yang memiliki keyakinan dan kesadaran seperti ini menjadi lebih terbuka dan toleran. Kehadiran agama yang lain tidak menjadi ancaman bagi eksistensinya. Sebab kekhasan suatu agama tidak berkaitan dengan masalah superioritas. Artinya bahwa setiap agama itu memang unik atau khas (hanya satu-satunya dalam jenis itu) tetapi itu tidak identik dengan lebih hebat atau superior. Kita tidak bisa menghindari diri dan menghapus keberagaman untuk mencapai homogenitas. Identitas tiap kelompok tetap dipertahankan tanpa membentuk suatu dialektika dalam pergaulan. Persoalannya adalah bagaimana kita bisa menciptakan kesadaran bersama sebagai suatu bangsa tanpa terkungkung dalam kotak eksklusif. Realitas kemajemukan agama yang ada di Indonesia meniscayakan adanya dialog. Dengan menjalankan dialog, masing-masing penganut agama semakin melangkah menuju ciri khas penghayatan imannya yang lebih menyapa, inklusif (terbuka), dan dialogis. ${ }^{27}$ Dialog merupakan cara terbaik untuk mempromosikan pemahaman yang lebih baik antara berbagai kelompok agama. Agamaagama harus mempunyai keterbukaan untuk berdialog. Dialog tidak dimaksudkan supaya kita lebur menjadi satu. Kita bertemu agar

26 Anis Malik Thoha, "Mencermati Doktrin dan Ciri-Ciri Fahaman Pluralisme Agama," in simposium Wacana Pemikiran dan Pembinaan Ummah 2 (Kuala Lumpur: Pertubuhan Muafakat Sejahtera Masyarakat Malaysia (MUAFAKAT), Jabatan Kemajuan Islam Malaysia (JAKIM), Jabatan Agama Islam Selangor (JAIS), Allied Coordinating Committee of Islamic NGOs (ACCIN) dan Permuafakatan Badan Amal Islam Wilayah Persekutuan, 2010), 5.

\footnotetext{
${ }^{27}$ Riyanto, Dialog Agama Dalam pandangan
} Gereja Katolik, 17. 
sikap saling memahami antarpemeluk agama bertumbuh dan berkembang. Menumbuhkan kesadaran ini jauh lebih penting ketimbang membuat aturan bagi terciptanya kerukunan.

Selain itu, setiap agama harus memiliki perspektif yang positif (positive thingking) jika ingin hidup aman dan damai dalam konteks pluralitas kehidupan beragama. Dengan itu, setiap agama akan berusaha untuk menampakkan lebih baik kesempurnaan Tuhan dan tidak akan jatuh dalam bahaya relativisme. ${ }^{28}$ Dialog antaragama merupakan suatu momentum berharga bagi setiap agama untuk memperlihatkan kekhasan agamanya. Dialog menjadi sarana yang istimewa bagi setiap agama untuk menjadi lebih terbuka dalam menyeringkan kekhasan agamanya. Selain itu, dialog antaragama menjadi medan perjumpaan setiap agama untuk mencari, mengenali dan menyadari kehadiran Tuhan melalui peristiwaperistiwa nyata kehidupan manusia. Dengan mengembangkan dialog seperti ini, maka pluralitas kehidupan beragama tidak akan dipandang sebagai sesuatu yang memang berbeda, tetapi justru dilihat sebagai suatu kekayaan kehidupan bersama untuk mengungkapkan kesempurnaan Tuhan. Menurut Schillebeeckx dalam Hariyatmoko, ${ }^{29}$ Tuhan begitu kaya dan sangat tak terbatas, sehingga tradisi agama tertentu yang bersifat terbatas tidak akan mampu memahami dan mengenali kesempurnaan dan kepenuhan Tuhan. Pernyataan ini menjadi landasan dialog antaragama. Dengan itu, setiap agama secara serius menghormati kekhasaan dan kekayaan nilai-nilai yang dimiliki setiap agama. Artinya, setiap agama tidak akan menyatakan diri sebagai pemegang kebenaran yang absolut atau mutlak.

Dialog yang perlu dilakukan untuk konteks sekarang adalah dialog kehidupan atau dialog tentang kehidupan, dan bukan hanya dialog spekulatif tentang Allah yang kadang berkesan

28 Haryatmoko, Dominasi Penuh Muslihat- Akar Kekerasan dan Diskriminasi, 103.

29 Haryatmoko, Dominasi Penuh Muslihat-Akar Kekerasan dan Diskriminasi, 103. sangat apologis. ${ }^{30}$ Dialog yang seharusnya berkembang saat ini adalah dialog yang bersifat antropologis. Dengan demikian, dialog yang dibangun bersama antara agamaagama menjadi sungguh berpijak dan berpihak. Dialog semacam ini dapat membantu setiap umat beragama untuk menjadi lebih manusiawi, religius, mencintai sesamanya dan terutama lebih mencintai Sang Pencipta. Dialog selalu berorientasi pada usaha untuk mengatasi realitas saling mencurigai yang pernah terjadi. Serentak dengan itu, dialog menjadi sebuah jalan dialektika menuju pemurnian hidup bersama (proses purifikasi).

Walaupun demikian, masalah keyakinan yang bersifat teologis perlu juga didialogkan agar umat beragama dapat memahami agama orang lain dan berusaha mempelajari dan menafsirkan sejarah setiap agama dengan tepat. Dialog teologis ini tidak dalam konteks untuk mencari kelemahan atau kekurangan dalam agama yang lain, tetapi bertujuan untuk saling memahami dan mengakui perbedaan yang hakiki dalam setiap agama. Dengan itu, setiap agama diajak untuk tidak mendominasi yang lain. Tentang hal ini, Levinas dalam Hariyatmoko ${ }^{31}$ menegaskan bahwa dialog tidak berarti menetralisir agama, tetapi berusaha untuk memelihara otentisitas atau keaslian setiap agama. Setiap agama memang berbeda dan tidak akan mungkin dapat dileburkan menjadi satu. Pernyataan ini mau menegaskan bahwa perbedaan antaragama merupakan suatu kenyataan yang tak terbantahkan (faktisitas). Persoalan perbedaan tersebut tidak bisa dipecahkan hanya dalam bentuk pernyataan bahwa setiap agama saling melengkapi. Kita harus mengakui adanya perbedaan-perbedaan teologis antaragama. Dialog antaragama bukan berarti menganeksasi atau menggabungkan agama yang lain atau menolak agama yang lain. Dialog tidak bermaksud setiap agama memaksakan sudut pandang agama kepada penganut agama yang lain. Dialog antar-

\footnotetext{
${ }^{30}$ Andang, Agama yang Berpijak dan Berpihak, 85.

31 Haryatmoko, Dominasi Penuh Muslihat- Akar Kekerasan dan Diskriminasi, 104.
} 
agama bertujuan membangun sikap saling memercayai, menghargai dan menghormati antara agama. Inilah konsep kesadaran berdialog yang sebenarnya. Oleh karena itu, perlu ada keberaniaan untuk memulai suatu bentuk dialog yang bertujuan untuk saling memahami dan mengakui perbedaan serta untuk permurniaan hidup bersama. Pemurniaan hidup bersama untuk mencapai kedewasaan masing-masing pemeluk agama justru terjadi dalam perjumpaan yang saling meneguhkan dan menguatkan dengan sesama yang lain. Oleh karena itu, dialog membutuhkan komitmen sejati dan menyingkirkan berbagai prasangka buruk atau negatif (negative stereotype). Kesempatan dialog merupakan momen membangun komitmen baru untuk menghargai diferensitas atau keberbedaan dalam hubungan antaragama. Setiap agama harus menghindari atau membuang sikap-sikap indiferentisme. Sikap ini harus dicegah karena akan melahirkan sikap acuh tak acuh dan menampilkan sikap menggampangkan atau menyederhanakan (simplifikasi) pandangan tentang agamaagama sebagai sama saja semuanya. Sikap yang memandang agama sebagai sama saja merupakan sikap yang naif dan justru sangat merugikan iman setiap pemeluk agama.

Menyadari pentingnya dialog antar umat beragama ini, maka Gereja Katolik sejagad sukses menerjemahkan ajaran kasih Yesus Kristus di dalam sebuah aspek misi GerejaNya yakni dialog dengan umat beragama lain di dalam atmosfer keterbukaan dan ketulusan yang dilandasi kasih dan kebenaran oleh karena iman akan Kristus. Dengan itu, Gereja Katolik menghidupkan dan mengembangkan sebuah dinamika baru yang tepat untuk menyumbangkan bagiannya yang paling penting demi pengembangan kemanusiaan yang beradab dan demi kesejahteraan bersama. Kekerasan adalah musuh kekristenan. Dialog dan tukar pikiran sambil menjalin persahabatan dan kekeluargaan atas dasar kasih adalah jalan yang benar dan harus ditempuh kalau ingin hidup damai dan harmonis. Inilah pokok pewartaan ketika Gereja giat memajukan dialog antar umat beragama dan bukan sebuah upaya proselitisme atau tindak propaganda untuk pindah agama. Sebagai salah seorang penasehat di dalam Konsili Vatikan II, Josef Ratzinger yang kemudian dikenal dengan Paus Benediktus XVI, turut memaklumi segala dokumen Gereja yang dikeluarkan pada masa Konsili Vatikan II, termasuk Nostra Aetate yang diumumkan tepatnya pada tanggal 28 Oktober $1965 .^{32}$ Gereja Katolik dalam dokumen Nostra Aetate (NA 2) ${ }^{33}$ menegaskan bahwa :

Gereja Katolik tidak menolak apapun, yang ada dalam agama-agama lain. Semuanya itu serba benar dan suci. Gereja dituntut untuk memiliki sikap hormat yang tulus dan jujur. Serentak dengan itu, Gereja merenungkan cara-cara bertindak dan hidup, kaidahkaidah serta ajaran-ajaran, yang memang dalam banyak hal berbeda dari apa yang diyakini dan diajarkannya sendiri. Tetapi semuanya itu dapat memantulkan sinar kebenaran yang dapat menerangi semua orang. Gereja tiada hentinya mewartakan dan wajib mewartakan Kristus, yakni "jalan, kebenaran dan hidup (Yohanes 14:6). Dalam Dia, manusia menemukan kepenuhan hidup keagamaan. Dalam Dia pula Allah mendamaikan segala sesuatu dengan diri-Nya.

Itulah sebabnya, Paus Benediktus XVI dengan caranya yang sangat teliti dan akurat, mengembangkan dan menghidupkan dialog antar umat beragama selama delapan tahun pontifikalnya dan tidak henti-hentinya berjuang untuk meletakkan dasar kekristenan yang solid melalui telaahan-telaahan teologisnya, agar di dalam dialog tidak terjadi kebimbangan, ketidaktahuan, kekocar-kaciran identitas dan lebih lagi sinkretisme teologis.

Relevansi dialog antar umat beragama yang dicanangkan Nostra Aetate tahun 1965 selama Konsili Vatikan II kini digarisbawahi

32 Markus Solo Kewuta, "Dialog: Tribute untuk Paus EM. Benediktus XVI," Jurnal Ledalero 12, no. 2 (2013), 285, http://www.ejurnal.stfkledalero.ac.id/index.php/JLe/article/view/92.

33 Dokumen Konsili Vatikan II Pernyataan Tentang Hubungan Gereja Dengan Agama-agama Bukan Kristiani (Nostra Aetate, 2), 1965. 
sekali lagi oleh Paus Fransiskus di dalam era kepemimpinannya. ${ }^{34}$ Itu berarti gema Nostra Aetate tetap nyaring. Bagi Paus Fransiskus, dialog antar umat beragama dalam rangka menyelesaikan problematika kehidupan bersama tidak saja diredusir menjadi tugas sebuah partai politik atau tugas pemaju-pemaju gerakan Justice and Peace atau intensi adorasi untuk kesalehan pribadi, melainkan hendaknya menjadi perhatian bersama lintas agama (common concern) yang tentunya bergema luas terhadap restorasi peradapan dunia. Oleh karena itu, ketika membaca gerak awal kiprah Paus Fransiskus ada harapan bahwa dialog merupakan kebutuhan dan keharusan atau harus berjalan terus dalam membangun relasi atau hubungan gereja dengan agama-agama bukan kristiani. Berkaitan dengan hal itu, maka bisa saja sisi kolaborasi lintas agama untuk perbaikan situasi sosial akan menjadi proyek utama selama masa pelayanan Paus Fransiskus, atau sisi rangkulan persahabatan ala Yohanes Paulus II yang akan menjadi targetnya, atau opsi peletakan landasan teologis ala Paus Benediktus XVI yang dijadikan sebagai prioritas dalam langkah strategi pengembangan semangat dialog antar umat beragama.

Sekalipun demikian, jika program pastoral Paus Fransiskus untuk dialog antarumat beragama bisa lebih menandaskan resiprositas (ketimbalikan) dan mencapai grassroots level (akar rumput), maka umat berbagai agama di seluruh dunia ibarat sedang memegang sapu ijuk dan giat menyapu-bersih pekarangannya sehingga "ketentraman" dan "kebersihan" (perdamaian dan keharmonisan) ditegakkan dari bawah. Dengan ini potensi perdamain dunia lebih real, karena justru grassroots level adalah wilayah abu-abu yang menurut pengalaman berbagai negara dunia masih sering diabaikan, padahal lebih memungkinkan terjadinya konflik sosial bernuansa SARA.

\section{b. Spiritualitas Passing Over}

34 Kewuta, "Dialog: Tribute untuk Paus EM. Benediktus XVI," 284-285.
Dialog antropologis antaragama perlu dikembangkan dalam suatu semangat yang disebut dengan spiritualitas passing over. Istilah passing over diperkenalkan oleh John S. Dunne yang dikutip oleh Komarudin Hidayat dan Ahmad Gaus AF. ${ }^{35}$ Passing over berarti melintas dari satu cara hidup ke cara hidup yang lain, dari satu agama kepada agama yang lain. Agama yang sudah mencapai tahap penghayatan religius yang tinggi, tidak akan mengungkung dirinya dan terpaku kaku pada ajaran formalisme-normatif-teologis belaka, tetapi terbuka dan melintasi agamanya sendiri dan masuk ke ruang religiositas (agama) lain. Pengembaraan religiositas ini meniscayakan adanya suatu dialog yang bersifat inklusif. Sebab sisi religiositas kehidupan beragama selalu memiliki wajah yang umum, manusiawi dan universal. Proses "melintas batas agama" (passing over) ini bertujuan untuk memperkaya khazanah religius, bukan untuk menghilangkan identitas agama. Sebab, pengenalan akan agama lain dapat mengantar kita untuk mengenal dan memahami lebih dalam agama sendiri. Oleh karena itu, proses melintas ini harus juga diikuti dengan proses kembali (coming back) dengan wawasan baru kepada cara hidup agama sendiri. Kedua proses ini harus dilakukan secara kreatif dan simpatik untuk memperkaya dan menambah wawasan baru setiap agama.

Berdasarkan pengertian di atas, maka dapat ditegaskan bahwa passing over lintas agama dan keyakinan adalah satu kemampuan untuk berdialog dengan agama atau keyakinan-keyakinan yang lain. ${ }^{36}$ Salah satu aspek pluralitas suatu komunitas ialah bervariasinya keyakinan agama yang dianut oleh para anggotanya. Di satu pihak, kehadiran berbagai agama dan keyakinan dalam suatu komunitas pluralis dapat menjadi satu kekayaan dan bersifat positif. Akan tetapi di pihak lain dapat juga menjadi tantangan yang berbahaya bagi

\footnotetext{
${ }^{35}$ Komaruddin, Hidayat \& Ahmad, Gaus, AF, eds., Passing Over: Melintas Batas Agama, xiv.

36 Frans Obon, Agama Flores, Politik Flores: Dinamika Kehidupan Agama dan Politik di Flores (Ende: Nusa Indah, 2012), 7-8.
} 
keyakinan-keyakinan atau antaragama. Kemampuan setiap individu atau kelompok untuk ber-passing over lintas keyakinan dan agama memiliki peran dan pengaruh yang besar terhadap keharmonisan hubungan di antara agama. Selain itu, menjadi sumber kekuatan bagi eksistensi atau keberadaan hidup setiap agama atau keyakinan.

Dengan kata lain, spiritualitas passing over memungkinkan keyakinan-keyakinan dan agama-agama yang berbeda bisa hidup berdampingan secara damai dalam suasana dialog saling menerima dan mengakui kehadiran masing-masing. ${ }^{37}$ Dalam suasana dialog seperti ini, para penganut agama-agama dan keyakinan-keyakinan yang berbeda merayakan perbedaan untuk saling memperkaya satu sama lain. Itu berarti bahwa spiritualitas passing over menjadi salah satu instrumen yang efektif untuk merajut kembali kemanusiaan yang sudah dikeping-keping dan bahkan sudah dikapling-kapling karena perbedaan agama. Perbedaan-perbedaan yang ada pada setiap agama dilihat sebagai suatu kekayaan yang memperat persatuan.

Salah satu cara untuk menjaga dan merawat perbedaan tersebut adalah dengan memperkuat dialog antaragama. Dialog antaragama yang berspiritualitas passing over juga mau mengakui pluralitas bahwa masyarakat kita beraneka ragam. ${ }^{38}$ Inilah dasar untuk membangun sikap dialog. Dialog antaragama dalam semangat passing over tidak bermaksud supaya setiap pemeluk agama lebur menjadi satu. Akan tetapi, setiap pemeluk agama bertemu dalam suasana dialog yang positif dan konstruktif untuk saling mendengarkan dan memahami kekayaan rohani setiap agama. Serentak dengan itu, setiap agama mau bertumbuh dan berkembang dalam suatu kesadaran untuk mendengarkan, memahami, menghormati dan menghargai sesama.

\footnotetext{
${ }^{37}$ Stephanus Turibius Rahmat, "Agama dan Konflik Sosial," Jurnal Pendidikan dan Kebudayaan Missio 8, no. 1 (2016), 141, http://ejournal.stkipsantupaulus.ac.id/index.php/jpkm/article/view/48.

${ }^{38}$ Obon, Agama Flores, Politik Flores- Dinamika Kehidupan Agama dan Politik di Flores, 289-290.
}

Setiap agama hendaknya membangun dialog dalam semangat passing over berlandaskan pada suatu keyakinan dasar bahwa setiap agama mempunyai dimensi perenis. ${ }^{39}$ Artinya bahwa setiap agama memiliki multidimensi dalam fungsinya. Dalam konteks inilah, kita dapat menemukan hal-hal yang menyatukan setiap agama. Hal yang menyatukan setiap agama justru dalam multidimensi fungsinya. Hakikat terdalam dari setiap agama dapat dilihat sebagai bentuk pengungkapan rasa kepatuhan pada Yang Transenden, Yang Absolut dan Imanen dalam berbagai bentuk simbol dan tradisi historis tertentu. Tetapi di pihak, agama tidak terlepas dari perspektif sosiologis kemasyarakatan. Dalam konteks ini, agama adalah fenomena sosial yang memiliki struktur dan fungsinya. Jika ditelisik lebih jauh dalam setiap agama ditemukan aspek-aspek dan hakikat yang sama. Terdapat hal-hal yang menyatukan setiap agama. Inilah yang disebut dengan dimensi perenis dari agama-agama. Ini berarti bahwa dalam setiap agama dan tradisi eksoteris (tradisi yang bersifat terbuka, pragmatis, sederhana, gamblang dan mudah dipahami dan dijalani oleh para penganutnya), kita menemukan warta dan pengetahuan yang sama yang terbungkus dalam berbagai bentuk tradisi dan simbol. Namun, terdapat kesatuan transendental yang harus dimengerti pada dimensi eksoteris.

Walaupun demikian, ada sebagian kelompok yang menilai bahwa strategi passing over (melintas batas agama) dalam mengembangkan dialog antaragama sebagai sesuatu yang melewati batas otoritas suatu agama. ${ }^{40}$ Sebab, setiap agama mempunyai wilayah spiritual yang otonom dan private (hubungan manusia dengan Tuhannya atau the ultimate. Jika suatu agama harus terlibat dalam dialog dengan spiritualitas passing over, maka harus berani keluar dari kungkungan arogansi, berani

\footnotetext{
39 Obon, Agama Flores, Politik Flores-Dinamika Kehidupan Agama dan Politik di Flores, 290-291.

40 "Membumikan Dialog Agama-Agama," Islam Lib, diakses 28 Desember 2017, http://islamlib.com/gagasan/pluralisme/membumikan-dialogagama-agama/.
} 
menangkal tindakan anarkis dan kaku dalam memahami agama. Intisari dialog antaragama lebih mengarah pada terjalinnnya komunikasi yang baik demi mewujudkan hubungan yang harmonis dalam kohesi sosial masyarakat antaragama. Oleh karena itu, proses dialog antaragama yang terjadi mesti diarahkan agar menghasilkan kebaikan bersama (bonum commune), tidak berpihak pada satu kelompok, menumbuhkan sikap saling pengertian (understanding) satu sama lain, dan mencari titik temu (persamaan) di antara agama-agama.

Teolog Sri Lanka yang bernama Aloysius Pieris mengatakan bahwa ada tiga (3) unsur yang terdapat dalam setiap agama. ${ }^{41}$ Pertama, pengalaman murni (pure experience). Rasa hormat dan kepatuhan kita sebagai makhluk tercipta pada Yang Absolut dan Transenden merupakan pengalaman inti dari agama. Bahwa kita mengalami sesuatu yang berada jauh di atas sana entah apa namanya tergantung pada konteks historis. Oleh karena itu, agama pun dilihat sebagai sesuatu yang mengatasi aspek institusional, simbol dan ritus. Kedua, kenangan bersama (collective memory) yakni perayaan akan pengalaman murni itu dalam sebuah komunitas, dalam kebersamaan. Di situ lahir berbagai bentuk simbol dan ritus yang terjadi dalam konteks di mana perayaan itu berlangsung. Perbedaan simbol dan ritus terjadi karena konteks dan tempat perayaan berlangsung. Ketiga, penafsiran (interpretation). Pada level ini, pengalaman akan Yang Absolut itu dicari aktualitasnya dalam kehidupan harian. Jika aspek penafsiran ini tidak berfungsi di dalam agama-agama, agama kehilangan makna dan relevansinya. Bila agama kehilangan daya tafsir dalam konteks kehidupan bersama dalam realitas sosial kemasyarakatan, spiritualitas sosial tidak akan muncul. Upaya untuk menghasilkan teologi yang membaharui kehidupan masyarakat tidak akan pernah terwujud atau berhasil.

Dimensi perenial agama dapat dijadikan kerangka acuan bagi praksis sosial agama di mana realitas sosial beserta seluruh komplek-

\footnotetext{
41 Obon, Agama Flores, Politik Flores-Dinamika
} Kehidupan Agama dan Politik di Flores, 291-292. sitas masalah sosial kehidupan menjadi perhatian utama. Kalau dilihat dalam konteks teologi agama-agama (theology of religions), teologi semacam inilah yang akan melahirkan pemikiran alternatif berkaitan dengan spiritualitas sosial yang menjunjung tinggi martabat manusia dan memperjuangkan realisasinya. Oleh karena itu, apa yang penting disini adalah bagaimana agama-agama mencari format baru dialog mereka untuk memperbaharui masyarakat. Format baru dialog transformatif yang mendorong perubahan di dalam masyarakat. Masalah kemiskinan, hak asasi manusia, dan masalah kemanusiaan lainnya menjadi medan bagi pengalaman religius semua agama.

Perubahan dan pembebasan masyarakat dari berbagai persoalan memerlukan pendekatan interkultural, interreligius, dan berbasiskan pengalaman agama-agama yang diperolehnya dari interaksi antara refleksi teologis dalam menanggapi realitas sosial dan tindakan konkret (aksi). Di sini, menjadi jelas bahwa setiap agama perlu terlibat dalam dialog supaya saling memperkaya dan mempertajam visi masing-masing demi suatu praktis di lapangan kehidupan. Dengan demikian, keprihatinan bersama setiap agama akan menjadi tanggung jawab iman. Pengakuan iman yang benar dari setiap pemeluk agama harus nyata dalam aksi dan praksis hidup. Iman yang benar harus dapat dipertanggungjawab serta memperoleh perwujudan dalam suatu aksi kemanusiaan seperti membela kebenaran, menegakkan keadilan, memperjuangkan harkat dan martabat manusia serta bersuara atas nama orang-orang yang tidak mampu bersuara (voice of the voiceless). Iman kepada Allah hanya benar kalau terwujud dalam hormat terhadap manusia ciptaan tertinggi Allah. Dengan kata lain, iman yang tidak disertai sikap positif terhadap manusia belum merupakan iman dalam arti yang sebenarnya. Itulah sebabnya, Gus Dur mengatakan bahwa "tidak penting apa agamamu atau sukumu, kalau kamu bisa melakukan sesuatu yang baik untuk semua orang. Orang tidak akan pernah 
tanya apa agamamu."42 Ajaran agama mesti tampak dalam praksis hidup yang nyata. Semua agama dipanggil untuk berjuang atas nama kemanusiaan. Itulah sebabnya, upaya menumbuhkan dan mengembangkan dialog menjadi kebutuhan urgen dan relevan bagi manusia yang hidup dalam konteks pluralisme. ${ }^{43}$ Dialog yang dibangun bukan bertujuan mencari titik kesamaan atau keragaman di antara pihak-pihak yang terlibat dalam dialog, tetapi mengakomodir pelbagai perbedaan sebuah konsensus bersama yang adil. ${ }^{44}$ Makna dialog antropologis antaragama dalam semangat passing over justru terletak dalam usaha membangun relasi harmonis di tengah realitas perbedaan. Oleh karena itu, sikap menerima, mengakui dan menghargai dimensi-dimensi perbedaan yang ada pada setiap agama menjadi tuntutan yang bersifat mutlak. Agama sebagai salah satu fakta pluralistik secara positif dapat dijadikan sebagai medan yang tepat untuk menumbuhkan dan mengembangkan dialog. Dialog antaragama yang dilandasi oleh sikap menerima dan mengakui ajaran dan praktik agama yang berbeda menjadi unsur mendasar bagi penyelesaian konflik sosial yang dilatarbelakangi oleh perbedaan kepercayaan dan keyakinan. Pihakpihak yang berbeda tidak menganggap ajaran agamanya sebagai yang paling baik dan paling benar, tetapi menerima dan mengakui adanya nilai kebaikan dan kebenaran yang diajarkan

\footnotetext{
${ }^{42}$ Najmuddin Ajie, "Gur Dur Milik Kita," diakses 17 Oktober 2017, http://www.gurdurian.net/id/article/opini/Gus-Dur-Milik-Kita/.

43 Raga Polikarpus, "Dialog Antaragama Dalam Perspektif Rational Komunikatif Jurgen Hubermas," Jurnal Pendidikan dan Kebudayaan Missio 3, no. 1 (2011), 113-114.

${ }^{44}$ Baca dan bandingkan dengan isu pluralisme sivik, yaitu konsep mengenai konsensus kewarganegaraan yang adil dan demokratis yang meletakkan semua keragaman kelompok warga masyarakat dalam posisi setara hak dan kewajibannya, serta bisa hidup bersama secara adil, saling menghargai, tanpa saling meniadakan. Lihat, Suhadi Cholil et al., Laporan Tahunan Kehidupan Beragama di Indonesia 2009 (Yogyakarta: Center for Religious and Cross-cultural Studies/CRCS, Sekolah Pascasarjana, Universitas Gadjah Mada, 2009), 9-10.
}

dalam agama-agama lain. Dengan demikian, dialog antropologis antaragama berorientasi pada upaya membangun dan membina saling pengertian dan saling pemahaman di antara pihak-pihak yang berbeda.

Dalam dialog ini, agama tidak lagi dilihat secara partikular yang hanya berperan dalam kelompok sosial tertentu, tetapi dimengerti dan dipahami secara holistik dan universal, yakni sebagai tanggapan atau jawaban positif dari semua umat beragama terhadap situasi penderitaan dan ketidakadilan yang dialami manusia secara universal. Dialog antropologis antaragama yang berspiritualitas passing over justru mendapat kekuatan yang luar biasa jika setiap agama berperan dalam memberikan solusi bagi penyelesaian masalah-masalah kemanusiaan yang dialami manusia secara universal. Oleh karena itu, setiap agama perlu melakukan transformasi diri dengan membangun kesadaran yang semakin mendalam dan terbuka akan perlunya solidaritas, serta menerima kemajemukan kehidupan beragama sebagai Kenyataan yang tidak bisa dielakkan. Menurut A. Sudiarja, transformasi semacam ini perlu dijalankan jika semua agama tidak mau kehilangan "kairos" (saat yang pas) dan membeku dalam "kronos" (sejarah) yang sebentar lagi akan menjadi masa lampau. ${ }^{45}$ Dialog antaragama yang bersifat arif, positif, konstruktif dan transformatif merupakan jalan menuju penghayatan agama yang autentik dan membumi. Agama yang sejati dan hebat adalah agama yang penganutnya terlibat dalam aneka persoalan kemanusiaan yang bersifat universal. Setiap agama harus berkomitmen untuk menyerukan dan memperjuangkan agama yang menunjung tinggi nilai kemanusiaan.

Jika demikian, maka setiap agama dipanggil untuk secara tegas menolak keagamaan dengan wajah keras, keagamaan yang mengancam, membenci dan meremehkan mereka yang berbeda. Semua agama harus keluar dari kungkungan arogansi dan bersatu untuk menolak segala kekerasan atas nama agama. Sebab, menurut Franz Magnis Suseno, iman kita

\footnotetext{
45 A. Sudiarja, Agama (di Zaman) yang Berubah (Yogyakarta: Kanisius, 2006), 167.
} 
masing-masing hanya akan dapat dipercayai, kalau keagamaan kita rendah hati dan baik hati. $^{46}$ Itu berarti bahwa agama atau segenap agama mesti dapat dirasakan sebagai sesuatu yang positif. Setiap penganut agama seharusnya memberikan kesaksian atau memancarkan kebaikan "Yang Ilahi" melalui kebaikan kita sendiri. Dengan demikian, siapa pun yang tulus hatinya, apa pun keyakinan agamanya mesti merasa aman dengan kita dan mendapat perlindungan. Di sinilah berlaku seruan Nurcholish Madjid bahwa kita "harus kembali percaya sepenuhnya pada kemanusiaan."47 Artinya, semua agama yang berbeda-beda mempunyai komitmen yang sama dalam semangat aksi kolektif (collective action) berperan sebagai rahmat bagi seluruh alam, tanpa kecuali. Menurut Gus Dur bahwa kerukunan dan kedamaian antar umat beragama yang sejati adalah ketika setiap agama mampu melihat titik-titik persamaan, dan menggunakannya untuk kepentingan bersama. Karena itu, menurut Gus Dur "yang sama jangan dibeda-bedakan, yang beda jangan disama-samakan."48 Dialog antropologis antaragama dalam spiritualitas passing over sebagai salah satu strategi untuk mengembangkan sikap saling memahami perbedaan antara agama, menciptakan kehidupan beragama yang harmonis, damai, dan toleran serta berjuang bersama menjunjung tinggi nilai-nilai kemanusiaan.

\section{SIMPULAN}

Dialog antropologis dengan spiritualitas passing over merupakan, salah satu bentuk interaksi dalam dialog antaragama, atau komunikasi positif dan konstruktif yang ber-

46 Franz Magnis, "Agama, Kebangsaan dan Demokrasi: Nurcholish Madjid dan Kemanusiaan.”, 17.

${ }^{47}$ Dikutip Franz Magnis, "Agama, Kebangsaan dan Demokrasi: Nurcholish Madjid dan Kemanusiaan.", 18.

${ }^{48}$ Dikutip Alissa Wahid, "Agama dan Hirarki Nilai dalam praktik Kebangsaan Indonesia," dalam Keterbukaan dan Demokrasi: Tantangan dan Harapan, ed. oleh Ayu Mellisa dan Husni Mubarok (Jakarta: Pusat Studi Agama dan Demokrasi Yayasan Paramadina bekerja sama dengan The Asia Foundation dan The Ford Foundation, 2015), 66. orientasi pada terciptanya rasa aman dan perdamaian dalam kehidupan beragama, berdasarkan spiritualitas passing over, dimana semua agama memiliki semangat awal kehadiran yakni agama berperan untuk menerangi (iluminatif), kenabian (profetis), membebaskan (liberatif), dan mengubah (transformatif). Semua penganut agama harus hadir secara terus-menerus untuk menumbuhkan semangat toleransi, memperjuangkan perdamaian tanpa kekerasan, dan menyelesaikan masalah kemanusiaan.

Dialog antropologis antaragama yang bersemangat passing over menjadi salah satu kekuatan yang dapat meretas perbedaan di tengah-tengah pluralitas kehidupan beragama. Jika semangat ini menjadi pilihan dasar (optio fundamentalis) setiap umat beragama, maka niscaya setiap agama secara terus menerus mengembangkan semangat toleransi, semangat dialog yang positif dan konstruktif serta memperjuangkan perdamaian tanpa kekerasan (non violence).

Setiap penganut agama dipanggil untuk memuliakan Tuhan dengan mendudukkan kembali religiositas keberagamaannya demi pengabdiaan kepada manusia. Sebab beragama berarti memuliakan Tuhan dengan memanusiakan manusia (Gloria Dei Homo Vivens). Dialog antropologis antaragama dalam semangat passing over bertujuan untuk menciptakan komitmen bersama setiap agama untuk memperjuangkan nilai-nilai kemanusiaan. Dialog seperti ini akan memperkaya setiap agama, mengembangkan kerja sama yang konstruktif serta membuat kehidupan bersama semakin rukun dan damai.

\section{DAFTAR PUSTAKA}

Ali, A.Mukti. "Ilmu Perbandingan Agama, Dialog, Dakwah dan Misi." In Ilmu Perbandingan Agama di Indonesia dan Belanda, diedit oleh Burhanuddin Daja dan Herman Leonard Beck. Jakarta: INIS, 1992.

Amaliyah, Efa Ida. "Makna Pluralitas Agama di Kalangan Mahasiswa STAIN Kudus dan Implementasinya Melalui Mata Kuliah Perbandingan Agama." Wawasan: Jurnal 
Ilmiah Agama dan Sosial Budaya 2, no. 1 (30 Juni 2017): 1 . doi:10.15575/jw.v2i1.587.

Andang, Al. Agama yang Berpijak dan Berpihak. Yogyakarta: Kanisius, 1998.

Cholil, Suhadi, Zainal Abidin Bagir, Mustaghfiroh Rahayu, dan Budi Asyhari. Laporan Tahunan Kehidupan Beragama di Indonesia 2009. Yogyakarta: Center for Religious and Cross-cultural Studies/CRCS, Sekolah Pascasarjana, Universitas Gadjah Mada, 2009.

Dagun, M, Save. Kamus Besar Ilmu Pengetahuan. Jakarta: Lembaga Pengkajian Kebudayaan Nusantara, 2006.

Franz Magnis, Suseno. "Agama, Kebangsaan dan Demokrasi: Nurcholish Madjid dan Kemanusiaan." In Agama, Keterbukaan dan Demokrasi : Tantangan dan Harapan, diedit oleh Ayu Mellisa dan Husni Mubarok. Jakarta: Pusat Studi Agama dan Demokrasi Yayasan Paramadina bekerjasama dengan The Asia Foundation dan The Ford Foundation, 2015.

Halim, Abdul. "Pluralisme dan Dialog Antar Agama." TAJDID 14, no. 1 (2015): 35-62. http://e-

journal.iainjambi.ac.id/index.php/tajdid/arti cle/view/734.

Haryatmoko. Dominasi Penuh Muslihat Akar Kekerasan dan Diskriminasi. Jakarta: Gramedia, 2010.

Heuken, Adolf. Ensiklopedi Gereja I, A-G. Jakarta: Yayasan Cipta Loka Caraka, 1991.

Hidayat, Komaruddin, dan Ahmad Gaus AF, ed. Passing Over: Melintas Batas Agama. Jakarta: Gramedia Pustaka Utama, 1998.

Juned, Mawardi. "Reaktualisasi Kerukunan Antar Umat Beragama Dalam Kemajemukan Sosial." Substantia 17, no. 1 (1 April 2015): 55-66. http://substantiajurnal.org/index.php/subs/ar ticle/view/129/0.

Kewuta, Markus Solo. "Dialog: Tribute untuk Paus EM. Benediktus XVI." Jurnal Ledalero 12, no. 2 (2013): 271-88. http://www.ejurnal.stfkledalero.ac.id/index. php/JLe/article/view/92.

Khotimah. "Dialog dan Kerukunan Antar
Umat Beragama." Jurnal Ushuluddin 17, no. 2 (2011): 214-24. doi:10.24014/JUSH.V17I2.693.

Kleden, Paul Budi. Dialog Antaragama dalam Terang Filsafat Proses Alfred North Whitehead. Maumere: Ledalero, 2001.

Kongregasi Evangelisasi Bangsa-Bngsa dan Dewan Kepausan Untuk Dialog Antaragama. Dialog dan PewartaanRefleksi dan Orientasi Mengenai Dialog Antaragama dan Pewartaan Injil Yesus Kristus. Maumere: LPBAJ, 1991.

Lindholm, Tore, W.Cole Durham, dan Bahia Tahzib-Lie, ed. Kebebasan Beragama atau Berkeyakinan Seberapa jauh?: Sebuah Referensi tentang Prinsip-Prinsip dan Praktek. Diterjemahkan oleh Rafael Edy Bosko dan M. Rifai'i Abduh. Kanisius, 2010.

Obon, Frans. Agama Flores, Politik Flores: Dinamika Kehidupan Agama dan Politik di Flores. Ende: Nusa Indah, 2012.

Polikarpus, Raga. "Dialog Antaragama Dalam Perspektif Rational Komunikatif Jurgen Hubermas." Jurnal Pendidikan dan Kebudayaan Missio 3, no. 1 (2011).

Qodim, Husnul. "The Differences Story of Isa (Jesus) in the Qur'an and the Bible: Study of Comparative Text." RELIGIOUS: Jurnal Agama dan Lintas Budaya 1, no. 1 (2012): 51-55.

Rifa'i, Afif. "Dialektika Pemikiran dalam Dialog Antar Umat Bergama-Studi Kasus Forum Persaudaraan Umat Beriman (FPUB) di Yogyakarta.” Jurnal Pemberdayaan Masyarakat: Media Pemikiran dan Dakwah Pembangunan 1, no. 1 (2017): 75-95. http://ejournal.uinsuka.ac.id/dakwah/JPMI/article/view/1131.

Riyanto, F.X.E. Armada. Dialog Agama dalam Pandangan Gereja Katolik. Yogyakarta: Kanisius, 1995.

Stephanus Turibius Rahmat. "Agama dan Konflik Sosial." Jurnal Pendidikan dan Kebudayaan Missio 8, no. 1 (2016): 13243.

http://ejournal.stkipsantupaulus.ac.id/index. php/jpkm/article/view/48.

Sudiarja, A. Agama (di Zaman) yang Berubah. 
Yogyakarta: Kanisius, 2006.

Thoha, Anis Malik. "Mencermati Doktrin dan Ciri-Ciri Fahaman Pluralisme Agama." In simposium Wacana Pemikiran dan Pembinaan Ummah 2. Kuala Lumpur: Pertubuhan Muafakat Sejahtera Masyarakat Malaysia (MUAFAKAT), Jabatan Kemajuan Islam Malaysia (JAKIM), Jabatan Agama Islam Selangor (JAIS), Allied Coordinating Committee of Islamic NGOs (ACCIN) dan Permuafakatan Badan Amal Islam Wilayah Persekutuan, 2010.

. Tren Pluralisme Agama, Tinjauan Kritis. Jakarta: Perspektif, 2005.

Wahid, Alissa. "Agama dan Hirarki Nilai dalam praktik Kebangsaan Indonesia." In Keterbukaan dan Demokrasi: Tantangan dan Harapan, diedit oleh Ayu Mellisa dan Husni Mubarok. Jakarta: Pusat Studi Agama dan Demokrasi Yayasan Paramadina bekerjasama dengan The Asia Foundation dan The Ford Foundation, 2015.
Yasin, Taslim HM. "Membangun Hubungan Antaragama Mewujudkan Dialog dan Kerjasama." Substantia 13, no. 1 (1 April 2011).

http://substantiajurnal.org/index.php/subs/a rticle/view/59.

\section{INTERNET}

Najmuddin Ajie, "Gur Dur Milik Kita," diakses $17 \quad$ Oktober 2017, http://www.gurdurian.net/id/article/opini/Gus-Dur-Milik-Kita/.

"Membumikan Dialog Agama-Agama," Islam Lib, diakses 28 Desember 2017, http://islamlib.com/gaga-

san/pluralisme/membumikan-dialogagama-agama/. 